\title{
Clathrina clara (Calcarea: Clathrinida: Clathrinidae) as foulers on onshore farmed oysters (Pinctada fucata)
}

\author{
S. VEENA AND P. LAXMILATHA \\ Visakhapatnam Regional Centre of Central Marine Fisheries Research Institute (CMFRI), Pandurangapuram, \\ Visakhapatnam-530003, Andhra Pradesh, India
}

\begin{abstract}
A calcareous sponge species was observed as a fouler in the onshore oyster culture tanks at Visakhapatnam Regional Centre of Central Marine Fisheries Research Institute (CMFRI). The sponge was collected and preserved for further studies. The material was deposited in the CMFRI museum. The species was identified as Clathrina clara (family Clathrinidae, order Clathrinida, subclass Calcinea, class Calcarea). The species is being recorded for the first time from Indian waters.
\end{abstract}

Keywords: Clathrinidae, Clathrina clara, fouler, oyster, Pinctada fucata

Submitted 16 December 2010; accepted 16 August 2011

\section{INTRDDUCTIDN}

Sponges are among the most ancestral metazoans (Medina et al., 2001) and may hold many clues to our understanding of the evolution of early animal and developmental processes (Martindale, 2005). The 'World Porifera Database' enlists 8132 valid species of sponges (van Soest et al., 2005). Sponges, besides their fundamental role in marine ecological processes, are an important source of secondary metabolites, useful for mankind in the pharmaceutical industry. However, of late, there has been a continuous threat to these sessile organisms due to habitat destruction and indiscriminate fishing activities (Vinod et al., 2007).

A sharp divide is apparent between information known about deep-water sponges and more poorly known, but richer, shallow-water sponges (Barnes \& Bell, 2002). Sublittorally, sponges are found mainly on hard rock substrates, but can occur on algae, or even loose on stable sediment bottoms (Picton et al., 2007). Massive or erect sponges are usually easy to spot, whereas encrusting sponges can be more cryptic owing to their small size and/or location (Picton et al., 2007).

A study on the diversity and taxonomy of sponges from different waters is of paramount importance as sponges are known to have both historical and evolutionary significance (Hooper \& van Soest, 2002). Many sponge species are notoriously difficult to identify, because morphological characters for comparative morphology are scarce and prone to homoplasies, highly variable or otherwise unsuitable for unambiguous identification and hence have frequently been regarded as widely distributed ('cosmopolitan') (Wörheide et al., 2007).

The class Calcarea (especially the Calcinea) has a reputation of being obscure and taxonomically difficult (Manuel

Corresponding author:

S. Veena

Email: veenashettigar@yahoo.co.in et al., 2002). However, the use of numerical analyses of shape, size and distribution of spicules, and detailed histology have thrown new light on the classification of Calcarea, revealing that the species diversity in calcareous sponges is much higher than was previously expected (Wörheide \& Hooper, 1999, 2002; Borojevic \& Klautau, 2000; Rapp et al., 2001; Rapp, 2004a, b).

The history of spongology of the Indian Ocean is rather a short one (Thomas, 2000). Thomas (1983) described 481 species of marine sponges while only 451 species have been reported from India by Pattanayak (1999). Sponges of class Demospongia are represented by the maximum number of species forming $88.8 \%$ followed by class Hexactinellida which represents $9.1 \%$ and the least by class Calcarea having only $2.1 \%$ of the total marine sponges from the Indian region (Thomas, 1983). There is a close relationship of the sponge fauna of the Indian Seas with that of the Australian region, Red Sea and the Pacific Ocean (Thomas, 1983). The sponge fauna of the Indian region is known from the papers of Carter (1887), Dendy (1916), Burton (1930, 1959), and Thomas $(1968,1984)$. Along the east coast of India Dendy (1887) and Ali (1954) described the sponge fauna of Madras while those of Orissa State were investigated by Annandale (1915) and Bapuji et al. (1999). Comparatively, poor data are known on the shallow-water marine sponge fauna of peninsular India. Shallow-water marine sponges collected from India were studied by Burton \& Rao (1932).

Sponges are well known for their association with other animals and plants (Bowerbank, 1873; Dendy, 1905, 1921; Annandale, 1911, 1914; Devanesan \& Chacko, 1941; Rao, 1941; Nayar \& Mahadevan, 1965). Sponges are known to occur as foulers and also in association with oysters (Annandale, 1914; Dharmaraj et al., 1987).

The aim of the present paper is to identify and report information about a calcareous sponge found during the routine cleaning operations of onshore oyster Pinctada fucata culture tanks. 


\section{MATERIALS AND METHODS}

A sponge sample was collected from the onshore pearl oyster (Pinctada fucata) culture tank of 1-ton capacity at a depth of a metre at Visakhapatnam Regional Centre of Central Marine Fisheries Research Institute (CMFRI). In situ information was first recorded, and photographs were taken using a Sony W220 camera. Laboratory studies encompass external morphology and skeletal arrangement. Morphology was noted and the specimen was observed under a stereomicroscope in order to analyse the anastomosis pattern of the cormus, distribution of oscula and the presence or absence of water-collecting tubes. The samples were preserved in ethanol for further study. Skeletals and spicules analysis was done using an Olympus compound microscope $10 \times$ and $40 \times$ objectives. Sections were prepared in order to analyse the organization of the skeleton and establish the presence or absence of cells with granules. The section was hand-cut using a clean scalpel mounted on a slide and analysed. For the spicule analysis, small pieces of the cormus were transferred to test tubes and dissolved in bleach. After digestion of the soft tissue, the spicules were spread out on microscopic slides and analysed. Measurements (length and width) of 34 spicules of each type were taken using an ocular micrometer. The results are presented in tabular form, featuring length (number, minimum, mean, maximum and SD $[\sigma]$ ) and width (number, mean and SD). Microphotographs of the spicules and sections were taken. Identification was done using the key and guide given by Hooper (2000), Klautau \& Valentine (2003) and Picton et al. (2007).

\section{SYSTEMATICS}

\section{Class CAlCarea Bowerbank, 1864 \\ Subclass CALCINEA Bidder, 1898 \\ Order CLATHRINIDA Hartman, 1958 \\ Family CLATHRINIDAE Minchin, 1900 \\ Genus Clathrina Gray, 1867 \\ Clathrina clara Klautau \& Valentine, 2003}

(Figures 1-2)

Synonym: Clathrina coriacea (Montagu, 1818).

\section{ETYMOLOGY}

Latin clarus (= bright). Describing the bright surface (Klautau \& Valentine, 2003).

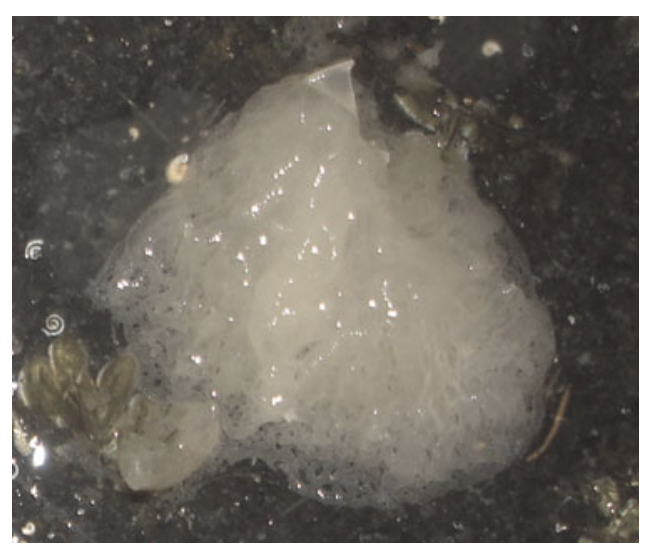

Fig. 1. Clathrina clara: specimens found on Pinctada fucata shell.

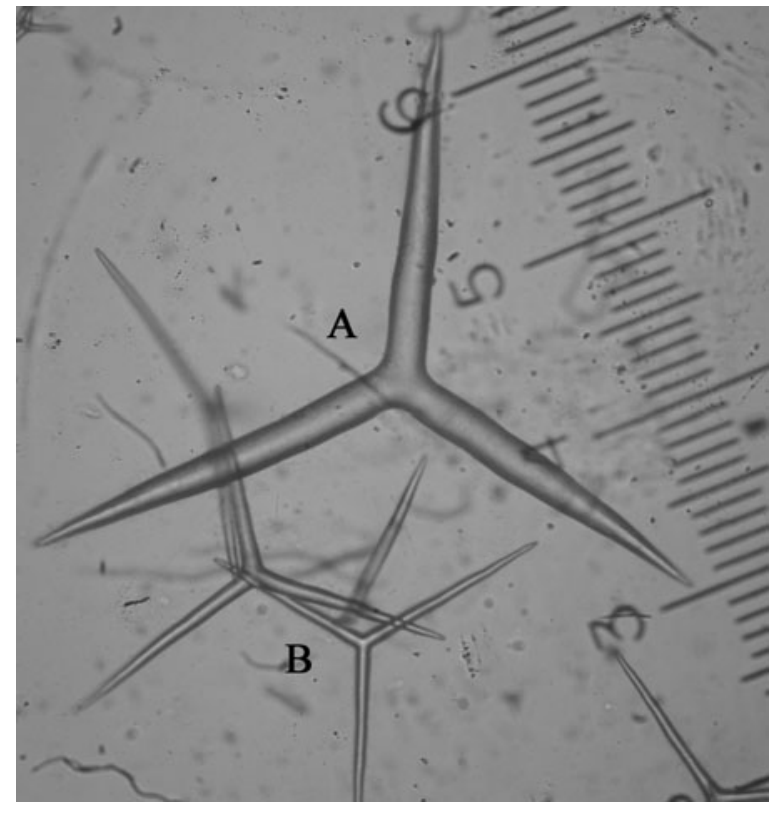

Fig. 2. Light microscopy view of Clathrina clara spicules: (A) large triactines; (B) small triactines.

\section{TYPE MATERIAL}

Diameter: $18 \mathrm{~mm}$; station: onshore tanks at Visakhapatnam Regional Centre of CMFRI; VSCC 1 , coll. S. Veena, 12 August 2010.

\section{DESCRIPTION}

Colour: live sponge was white and after preservation, light brown.

Consistency: soft and delicate.

Odour: none.

Contraction: no noticeable contraction when the animal was compressed.

\section{DIAGNOSIS}

Small, flat but not tubular and has meshes consisting of a network of thin walled tubes which are a compact mass attached directly to the substrate. The surface cormus comprises tightly-knit tubes, several tubes joining to share one common oscule, slightly raised above the surface (Figure 1). There are no erect free branches. Cells with granules were not observed. The skeleton comprises two size-classes of equiangular and equiradiate triactines (Figure 2). Actines are conical and straight, with a sharp tip. The large triactines are located only in the external tubes, delimiting the cormus, while the smaller triactines are found inside the cormus. The measurements are all tabulated (Table 1).

Table 1. Spicule measurements of Clathrina clara Klautau \& Valentine, 2003.

\begin{tabular}{|c|c|c|c|c|c|c|c|c|}
\hline & \multicolumn{5}{|c|}{ Length $(\mu \mathrm{m})$} & \multicolumn{3}{|c|}{ Width $(\boldsymbol{\mu m})$} \\
\hline & No. & Min. & Mean & $\boldsymbol{\sigma}$ & Max. & No. & Mean & $\boldsymbol{\sigma}$ \\
\hline Small triactines & 34 & 110.0 & 175.0 & 33.2 & 240.0 & 34 & 10.0 & 2.9 \\
\hline Large triactines & 34 & 300.0 & 330.0 & 21.3 & 360.0 & 34 & 18.0 & 2.1 \\
\hline
\end{tabular}

No., number; Min., minimum; $\sigma$, standard deviation; Max., maximum. 
HABITAT

The species was observed as a fouler on the oyster (Pinctada fucata) in onshore culture tanks.

\section{REMARKS}

Symbiotic association between this sponge and the oyster was noted since there was no external or internal damage observed on the oyster.

\section{DISCUSSIDN}

The genus Clathrina is defined almost exclusively by negative characters (Borojevic \& Boury-Esnault, 1987). Moreover, its skeleton is also simple, comprising only a few spicule types: diactine, triactine and/or tetractine. The genus Clathrina is represented by more than 40 described species in all seas (Klautau \& Valentine, 2003). The classification is difficult due to the existence of only a few, easily recognizable morphological criteria that can be used as descriptors, especially in species whose skeleton is composed only of triactines (Borojevic \& Boury-Esnault, 1987).

The use of statistical analyses of shape, size and distribution of spicules has thrown new light on the classification of the group, and previous numbers of species in any given geographical area are expected to be underestimated (Thomas, 1996; Wörheide \& Hooper, 1999; Borojevic \& Klautau, 2000; Klautau \& Borojevic, 2001; Rapp et al., 2001; Klautau \& Valentine, 2003; Rapp, 2004b).

The present species identification was done by studying the type of spicules and pattern of spicule arrangement. The large size of the triactines that remain on the surface of the tubes in Clathrina clara is enough to differentiate it from the other clathrinas (Klautau \& Valentine, 2003). The next feature is the tip of the actines which is sharp in Clathrina clara similar to that noted by Klautau \& Valentine (2003) whereas for the other species (blunt in C. ceylonensis, conical in C. coriacea and cylindrical in C. clathrus) as noted by Hooper (2000), Klautau \& Valentine (2003) and Picton et al., (2007). Hence these species were all ruled out. However, the species Clathrina primordialis is similar to C. clara since both have the tip of actines sharp and also two size-classes of triactines (Klautau \& Valentine, 2003). But it is easy to differentiate the two species by the anastomosis of the tubes (tight in Clathrina clara and loose in C. primordialis), and by the size of the spicules (Klautau \& Valentine, 2003). As recorded by Klautau \& Valentine (2003) the length and thickness of the two size-classes of triactines of Clathrina primordialis are $91.9 / 9.6 ; 86.6 / 11.3 \mu \mathrm{m}$, while in C. clara recorded in the present study are $175.0 / 10.0 ; 330.0 / 18.0 \mu \mathrm{m}$. Hence this species was confirmed as Clathrina clara. A note to be made here is that the size of the spicules of Clathrina clara differed when compared with the descriptions given by Klautau \& Valentine (2003) where they noted these as $84.5 / 9.8 \mu \mathrm{m}$; $164.5 / 21.8 \mu \mathrm{m}$. This difference may be due to the ambient environmental conditions. There are reports of putative environmental influences on spicule size in Demospongiae (Chondrilla) (Solé-Cava et al., 1991; Klautau et al., 1999) and in H. (Cyliconema) apertum apertum (Tabachnick \& Menshenina, 2002).

Sponges constitute a major group among 12 different taxa of marine animals and plants which can cause considerable damage to the calcium carbonate secreting animals such as molluscs, corals, barnacles, etc. (Thomas, 2000). Annandale (1911) discussed in detail the association of some sponges with molluscs of the family Vermetidae from the Bay of Bengal and in a later publication (Annandale, 1914) he dealt with similar association with oysters and mussels from the Madras Harbour. Dharmaraj et al. (1987) also studied the fouling and association with oysters. In the present study, no damage caused by the sponge to the oyster Pinctada fucata was noted during observation for a period of 4 months (August to December) and only symbiotic association was seen between the animals.

The number of calcareous species from the Indian Region, as now understood, comprises a total of ten widespread species (Thomas, 1983). Family Clathrinidae has henceforth not been described from Indian waters except Clathrina coriacea from Andaman waters (Pattanayak, 2006). Clathrina clara has been identified from the reefs at Christmas Island, Indian Ocean by Klautau \& Valentine (2003). The shallow-water sponges from this area have not been recorded and this study reports the identification of the present sample to the species level. This article reports Clathrina clara as a new species identified not only from this area but also adds this species as a new record to the taxonomic list for India.

\section{ACKNDWLEDGEMENTS}

The authors thank Dr G. Syda Rao, Director of CMFRI for his constant encouragements. We also thank Michelle Klautau, Universidade Federal do Rio de Janeiro, Instituto de Biologia-Departamento de Zoologia, Laboratório de Biologia de Porifera, Avenida Brigadeiro Trompowski, Ilha do Fundão-Rio de Janeiro, Brazil for her help with the identification; and Mrs Padmaja Rani for her help in acquiring the specimen. This research received no specific grant from any funding agency, commercial or not-for-profit sectors.

\section{REFERENCES}

Ali M.A. (1954) Studies on sponges. MSc thesis. University of Madras, Tamil Nadu, India.

Annandale N. (1911) Some sponges associated with gregarious molluscs of the family Vermetidae. Records of the Indian Museum 6, 47-56.

Annandale N. (1914) Fauna Symbiotica Indica, no. 5. Some sponges commonly associated with oysters and mussels in Madras Harbour and the Chilka Lake. Records of the Indian Museum 10, 149-158.

Annandale N. (1915) Fauna of Chilka Lake. Sponges. Memoirs of the Indian Museum 5, 23-54.

Bapuji M., Sree A., Mishra S., Vimala A., Sahu S.K., Choudhury S. and Thomas P.A. (1999) The new sponge resources of Orissa coast. Current Science 77, 220-222.

Barnes D.K.A. and Bell J.J. (2002) East African Wild Life Society. African Journal of Ecology 40, 337-349.

Borojevic R. and Boury-Esnault N. (1987) Calcareous sponges collected by N.O. Thalassa on the continental margin of the Bay of Biscay: I.Calcinea. In Vacelet J. and Boury-Esnault N. (eds) Taxonomy of Porifera from the north-east Atlantic and Mediterranean Sea. Berlin and Heidelberg: Springer-Verlag, pp. 1-27. [NATO Asi Series, G13.] 
Borojevic R. and Klautau M. (2000) Calcareous sponges from New Caledonia. Zoosystema 22, 187-201.

Bowerbank J.S. (1873) Report on a collection of sponges found at Ceylon by E.W.H. Holdsworth, Esq. Proceedings of the Zoological Society of London 1873, 25-32.

Burton M. (1930) Additions to the sponge fauna of the Gulf of Mannar. Annals and Magazine of Natural History 5, 665-676.

Burton M. (1959) Sponges. John Murray Expedition 1933-1934. Scientific Reports. British Museum (Natural History) 10, 151-281.

Burton M. and Rao H.S. (1932) Reports on the shallow-water marine sponges in the collection of the Indian Museum. Records of the Indian Museum 34, 299-356.

Carter H.J. (1887) Report on marine sponges, chiefly from King Island in the Mergui Archipelago, collected for the Trustees of the Indian Museum, Calcutta by Dr. John Anderson. Journal of the Linnean Society of London 21, 61-84.

Dendy A. (1887) The sponge fauna of Madras. A report on a collection of sponges obtained in the neighbourhood of Madras by Edgar Thurston. Annals and Magazine of Natural History 20, 153-164.

Dendy A. (1905) Report on the sponges collected by Prof. Herdman at Ceylon in 1902. Report to the Government of Ceylon Pearl Oyster Fisheries of Gulf of Mannar 18, Supplement, 57-246.

Dendy A. (1916) Report on the non-calcareous sponges collected by Mr. James Hornell at Okhamandal in Kattiawar in 1905-1906. Report to the Government of Baroda Marine Zoology Okhamandal 2, 96-146.

Dendy A. (1921) Report on Sigmatotetraxonida collected by H.M.S. 'Sealark' in the Indian Ocean. Transactions of the Linnean Society of London 18, 1-164.

Devanesan D.N. and Chacko P.I. (1941) Commensalism in sponges. Current Science 10, 1-374.

Dharmaraj S., Chellam A. and Velayudhan T.S. (1987) Biofouling, boring and predation of pearl oyster. Bulletin of the Central Marine Fisheries Research Institute, India 39, 92-97.

Hooper J.N.A. (2000) 'Sponguide'. Guide to sponge collection and identifcation. (available from http://www.qmuseum.qld.gov.au/organisation/ sections/SessileMarineInvertebrates/index.asp).

Hooper J.N.A. and Soest R.W.M. van (eds) (2002) Systema Porifera: a guide to the classification of sponges, I. New York: Kluwer Academic/ Plenum Publishers, pp. 1-3.

Klautau M. and Borojevic R. (2001) Calcareous sponges from Arraial do Cabo-Brazil (I: the genus Clathrina). Zoosystema 23, 395-410.

Klautau M., Russo C.A.M., Lazoski C., Boury-Esnault N., Thorpe J.P. and Solé-Cava A.M. (1999) Does cosmopolitanism result from overconservative systematics? A case study using the marine sponge Chondrilla nucula. Evolution 53, 1414-1422.

Klautau M. and Valentine C. (2003) Revision of the genus Clathrina (Porifera, Calcarea). Zoological Journal of the Linnean Society of London 139, 1-62.

Manuel M., Borojevic R., Boury-Esnault N. and Vacelet J. (2002) Class Calcarea Bowerbank, 1864. In Hooper J.N.A. and Soest R.W.M. van (eds) Systema Porifera. A guide to the classification of sponges. New York: Kluwer Academic/Plenum Publishers, pp. 1157-1184.

Martindale M.Q. (2005) The evolution of metazoan axial properties. Nature Reviews Genetics 6, 917-927.

Medina M., Collins A.G., Silberman J.D. and Sogin M.L. (2001) Evaluating hypotheses of basal animal phylogeny using complete sequences of large and small subunit rRNA. Proceedings of the
National Academy of Sciences of the United States of America 98, 9707-9712.

Nayar K.N. and Mahadevan S. (1965) Underwater ecological observations in the Gulf of Mannar of Tuticorin. II. The occurrence of synaptid Chondrocloea along with the massive sponge, Petrosia. Journal of the Marine Biological Association of India 7, 199-201.

Pattanayak J.G. (1999) Annotated checklist of marine sponges of Indian region. Memoirs of the Queensland Museum 44, 439-455.

Pattanayak J.G. (2006) Marine sponges of Andaman and Nicobar Islands, India. Occasional Papers. Records of the Zoological Survey of India 255, $1-164$.

Picton B.E., Morrow C.C. and Soest R.W.B. van (2007) Sponges of Britain and Ireland. (available from http://www.habitas.org.uk/marinelife/sponge_guide/introduction.html).

Rao H.S. (1941) Indian and Ceylon sponges of the Naturhistoriska Riksmuseet, Stockholm, collected by K. Fristedt. Records of the Indian Museum 43, 417-469.

Rapp H.T. (2004a) The first record of the genus Leucascus Dendy, 1892 from the Atlantic Ocean, with description of Leucascus lobatus sp. nov. (Porifera, Calcarea, Calcinea) from Greenland. Steenstrupia 28, $1-9$.

Rapp H.T. (2004b) A revision of calcareous sponges (Porifera, Calcarea) in coast and shelf areas of Norway and Greenland. $\mathrm{PhD}$ thesis. University of Bergen, Norway.

Rapp H.T., Klautau M. and Valentine C. (2001) Two new species of Clathrina (Porifera, Calcarea) from the Norwegian coast. Sarsia 86, $69-74$.

Soest R.W.M. van, Boury-Esnault N., Janussen D. and Hooper J.N.A. (2005) World Porifera Database. (available from http://www.vliz.be/ vmdcdata/porifera).

Solé-Cava A.M., Klautau M., Boury-Esnault N., Borojevic R. and Thorpe J.P. (1991) Genetic evidence for cryptic speciation in allopatric populations of two cosmopolitan species of the calcareous sponge Clathrina. Marine Biology 111, 381-386.

Tabachnick K.R. and Menshenina L.L. (2002) Family Hyalonematidae Gray, 1857. In Hooper J.N.A. and Soest R.W.M. van (eds.) Systema Porifera. A guide to the classification of sponges, II. New York: Kluwer Academic/Plenum Publishers, pp. 1232-1256.

Thomas P.A. (1968) Studies on sponges. PhD thesis. University of Kerala, Kerala, India.

Thomas P.A. (1983) Distribution and affinities of the sponge fauna of the Indian region. Journal of the Marine Biological Association of India 25, 7-16.

Thomas P.A. (1984) Sponges collected aboard R.V. Skipjack from the southeast coast of India. Journal of the Marine Biological Association of India 26, 95-102.

Thomas P.A. (1996) An appraisal of the biological and biochemical diversity in sponges. Marine Fisheries Information Service, Technical and Extension Series 142, 1-5.

Thomas P.A. (2000) Sponges - systematics, as pests of molluscs, agents of bioerosion and a source of bioactive compounds. In Pillai V.N. and Menon N.G. (eds) Marine Fisheries Research and Management. Kochi, India: Central Marine Fisheries Research Institute, pp. 109-123.

Vinod K., George Rani Mary, Sanil N.K., Jayaprakash A.A., Manjebrayakath Hashim and Thankappan Divya (2007) An account of hexactinellid sponge, Hyalonema (Cyliconema) apertum apertum collected from Andaman waters. Journal of the Marine Biological Association of India 49, 219-225. 
Wörheide G., Erpenbeck D. and Menke C. (2007) The Sponge Barcoding Project: aiding in the identification and description of poriferan taxa. Porifera Research: Biodiversity, Innovation and Sustainability 2007, $123-128$.

Wörheide G. and Hooper J.N.A. (1999) Calcarea from the Great Barrier Reef. I: Cryptic Calcinea from Heron Island and Wistari Reef (Capricorn-Bunker group). Memoirs of the Queensland Museum 43, 859-891.

and

Wörheide G. and Hooper J.N.A. (2002) New species of Calcaronea (Porifera: Calcarea) from cryptic habitats of the southern Great
Barrier Reef (Heron Island and Wistari Reef, Capricorn-Bunker Group, Australia). Journal of Natural History 37, 1-47.

\section{Correspondence should be addressed to:}

S. Veena

Visakhapatnam Regional Centre of CMFRI

Pandurangapuram

Visakhapatnam - 530003

Andhra Pradesh, India

email: veenashettigar@yahoo.co.in 